О.М. Храпкін

Державний університет інфраструктури та технологій, Київ

\title{
ЗАХИСТ ІНФОРМАЦІЙНО-КОМУНІКАЦІЙНОЇ МЕРЕЖІ УСТАНОВИ ВІД НЕСАНКЦІОНОВАНОГО ДОСТУПУ
}

У статті розглянуто питання можливості проникнення до інформаџійно-комунікаційної мережі установи, проаналізовано та симульовано дії реального порушника контурів захисту інформації на прикладі реальної інформаційної інфраструктури, наведено загальний порядок оцінювання та забезпечення вдосконалення систем захисту інформації шляхом проведення тестування на проникнення. Запропоновані методи проведення тестування на проникнення можуть використовуватись при розробиі та тестуванні нових систем захисту інформації, а також оцінювання ефективності та вдосконалення вже існуючих систем. Результати можуть бути використані в галузі захисту інформації, зокрема в сучасних інформаційнокомунікаційних системах та мережах (IКСM) для оцінювання та підвищення ефективності застосування комплексних систем та окремих засобів захисту інформації в сучасних IКСМ.

Ключові слова: захист інформації, несанкиіонований доступ, тестування на проникнення, оцінювання ефективності захисту, сочіальна інженерія, програмна інженерія, практичний захист інформації.

\section{Вступ}

Постановка проблеми. Проблеми захисту та оцінки даних інформаційних систем на даний час продовжують залишатися надзвичайно актуальними. Особливо важливими є завдання, пов'язані 3 оцінкою та захистом даних у системах, орієнтованих на співпрацю з обраними об'єктами та відповідними середовищами. Головна мета захисту інформаційних даних полягає у тому, щоб виключити можливість їх несанкціонованого використання або втрат у відповідному середовищі. Важливим напрямом протидії таким ситуаціям $\epsilon$ проведення періодичних перевірок захищеності системи шляхом тестувань на проникнення. Такий метод грунтується на реалізації різних способів проникнення до інформаційнокомунікаційної мережі, що імітують дії реального порушника, що дозволяє отримувати фактичні результати 3 питань дослідження рівня та стану інформаційної безпеки.

На сучасному етапі розвитку інформаційних систем оцінка рівня захищеності даних, на відміну від минулих уявлень, не є сталою, навіть у випадку, коли одночасно є декларацією рівня. Цей стан $є$ динамічною величиною, на значення якого може впливати кожна дія кожного елемента системи - від користувача до програмного запиту на рівні апаратури. Такі зміни можуть призводити до стрімкого зниження рівня інформаційної безпеки установи, що несе за собою великі економічні, політичні та соціальні збитки.

Наведені аспекти ілюструють складність задач, пов'язаних із забезпечення достовірного рівня ефективності моніторингу стану інформаційної безпеки установи. У зв'язку з цим задачі, що досліджуються та розв'язуються у дослідженні, є важливими та актуальними.

Аналіз останніх досліджень і публікацій. Дослідженням теми захисту інформаційнокомунікаційних мереж від несанкціонованого доступу займаються багато науковців, зокрема: Д. Белл, Л. Лападула, А. Йонез, Р. Ліптон, Л. Діон, А. Файнстайн, К. Йомен, К. Ландвер, К. Хайтмайер, Д. Уілсон, М. Харрісон, Я.Й. Малик, Ю.В. Землянко, та ін. Проблематикою забезпечення належного рівня захисту інформації в нормативно-правовому полі в тому числі займаються представники Кабінету Мiністрів України, представники комерційних та громадських організацій як в Україні, так і в світі. Дослідженнями 3 питання стандартизації програмних, апаратних та комплексних систем захисту інформації для держав та бізнесу займалися представники таких вагомих в світі інформаційних систем організацій як ISO/IEC, IETF, IEEE, Cisco, Oracle, Microsoft тa Google.

Метою статті $\epsilon$ дослідження систем захисту інформації в інформаційно-комунікаційній мережі установи та її вдосконалення.

\section{Виклад основного матеріалу}

У сучасному світі інформація є найціннішим ресурсом. Економічний, військовий, політичний потенціал у сучасному суспільстві переважно визначається обсягом інформаційних ресурсів та рівнем розвитку інформаційної інфраструктури. Інформація постійно ускладнюється, змінюється якісно, зростає кількість їі джерел і споживачів, а також 
збільшується рівень впливу інформаційних потоків на останніх. Водночас зростає уразливість сучасного інформаційного суспільства від недостовірної інформації, іiї несвоєчасності, недоступності, кіберзлочинності та промислового шпигунства, тощо [1], а отже виникає необхідність захисту інформації, а також систем та мереж, в яких вона зберігається та оброблюється від несанкціонованого доступу, порушення режиму доступу до неї, несанкціонованого модифікування, створення або знищення.

Закон України "Про захист інформації в інформаційно-телекомунікаційних системах” визначає захист інформації як діяльність, спрямовану на запобігання несанкціонованим діям щодо інформації в системі, а саму систему захисту як взаємопов'язану сукупність організаційних та інженерно-технічних заходів, засобів та методів захисту інформації [2].

На думку Тарнавського Ю.А. [3], захист інформації полягає не лише в захисті засобів обробки інформації, а і в організації засобів захисту для підтримки стану захищеності фундаментальних властивостей інформації в інформаційнотелекомунікаційних системах.

Системи обробки інформації дедалі більше розповсюджуються і займають все більшу нішу в житті сучасного суспільства, а також окремих його елементів на різних рівнях - від окремих особистостей до державних апаратів, що, відповідно, збільшує необхідність розробки нових систем захисту інформації в інформаційно-комунікаційних мережах та удосконалення вже існуючих та впроваджених. Сутність поняття інформаційно-комунікаційних систем, на думку Маслянко П.П. [4], полягає у взаємопов'язаній сукупності інформаційних та телекомунікаційних систем, які в процесі обробки інформаційних потоків діють як одне ціле.

Івановою О.М. [5] розроблено одну з базисних моделей характеристики і класифікації інформаційних потоків на прикладі суб'єктів господарювання (установ). Так, за думкою автора, генераторами та отримувачами інформаційних потоків $є$ кожен елемент, незалежно від його рівня чи позиції в організаційній структурі суб'єкта господарювання, до якого він належить, а також, будучи генератором (емітером) потоків, має мати прямий та зворотній зв'язок із своїми отримувачами (реципієнтами).

Побудова будь-якої системи захисту інформації регламентується законодавством України [6-7], нормативними актами Кабінету Міністрів, держаними та міжнародними технічними стандартами 3 питань інформаційної безпеки, а також розпорядчими документами, що підписані керівником установи та/або замовником створення комплексної системи захисту інформацію та не протирічать діючому законодавству та одне одному.
Розвиток нормативно-правового забезпечення безпеки інформаційно-телекомунікаційних систем, мереж зв'язку та використання Інтернету може позитивно відобразитися на захисті національних інтересів у процесі міжнародного співробітництва, оскільки на поточний момент законодавство України значно відстає від існуючого Європейського нормативно-правового поля. Окрім іншого, правове забезпечення захисту інформації включає в себе прогнозування: ризиків державної внутрішньої i зовнішньої політики, соціально-економічного розвитку, державного будівництва; потенційних і реальних інформаційних загроз, викликів і небезпек.

Спеціальне законодавство у сфері безпеки інформаційної діяльності (інформаційної безпеки) може бути представлено сукупністю законів. Особливе місце серед них належить базовому Закону “Про інформацію”, що визначає основу правового визначення всіх найважливіших компонентів інформаційної діяльності. Даний закон закріплює право громадян України на інформацію, закладає правові основи інформаційної діяльності. Даний закон є базисним, його доповнюють Доктрина інформаційної безпеки України [7], закони, які забезпечують інформаційну безпеку в конкретних сферах життєдіяльності особи, суспільства, держави за напрямами державної політики забезпечення інформаційної безпеки: політичній, економічній, оборонній, державної безпеки і правопорядку, соціальногуманітарній, науково-технологічній, екологічній, інформаційній галузях, а також різного роду підзаконні нормативні акти, які регулюють правовідносини у сфері забезпечення інформаційної безпеки, що стосуються взаємодії органів державної влади, координації діяльності $з$ цих питань, тощо.

Залежно від своєї важливості, інформація підлягає різним рівням захисту, що обумовлюється адекватністю засобів захисту, що визначено в постанові Кабінету Міністрів України "Про затвердження Концепції технічного захисту інформації в Україні" [8]. Генеральну класифікацію інформації в нормативно-правовому полі визначено Законом України "Про інформацію" [9]. Законодавством та сучасними технічними стандартами не визначено чітких меж засобів захисту інформації, а отже відповідальність за збереження конфіденційності, доступності, цілісності, актуальності та інших властивостей інформації (що, по суті, є статусом захищеності інформації), а також вибір засобів, заходів та методів захисту інформації цілком покладається на розсуд власника інформації, а також (у випадку інформації, що містить державну таємницю) на розсуд компетентних правоохоронних органів, що означає індивідуальний підхід для кожного окремого випадку, що є коректним в обставинах неоднозначності 
визначення цінності інформації залежно від ii вмісту.

Так, Нашинець-Наумова А.Ю. [1] пропонує до використання зразок абстрактної моделі організаційного захисту інформації залежно від наступних чинників:

- переліки захищених відомостей, що складають державну чи комерційну таємницю;

- необхідні рівні безпеки інформації, забезпечення яких не призведе до перевищення збитків над витратами щодо захисту інформації;

- загрози безпеці інформації;

- показники, за якими оцінюватиметься ефективність захисту інформації.

Однак, у вищезазначеній роботі, як і в законодавстві, і в державних та міжнародних стандартах, не визначено жодних конкретних показників, а отже їх визначення залишається індивідуальним для кожного окремого випадку до впровадження законодавством України або міжнародними організаціями 3 питань стандартизації в галузі захисту інформації даних показників. Однією з таких прогалин в системі захисту інформації $є$ відсутність уніфікованої моделі захисту інформації. Більша частина дослідників згодна між собою в загальній концепції щодо етапів формування системи захисту інформації, що була запропонована в стандарті НД ТЗІ 3.7-003-05 "Порядок проведення робіт із створення комплексної системи захисту інформації в інформаційнотелекомунікаційній системі" [11]. Дана загальна концепція визначає наступні основні етапи створення систем захисту інформації в різних суб'єктах господарювання (рис. 1).

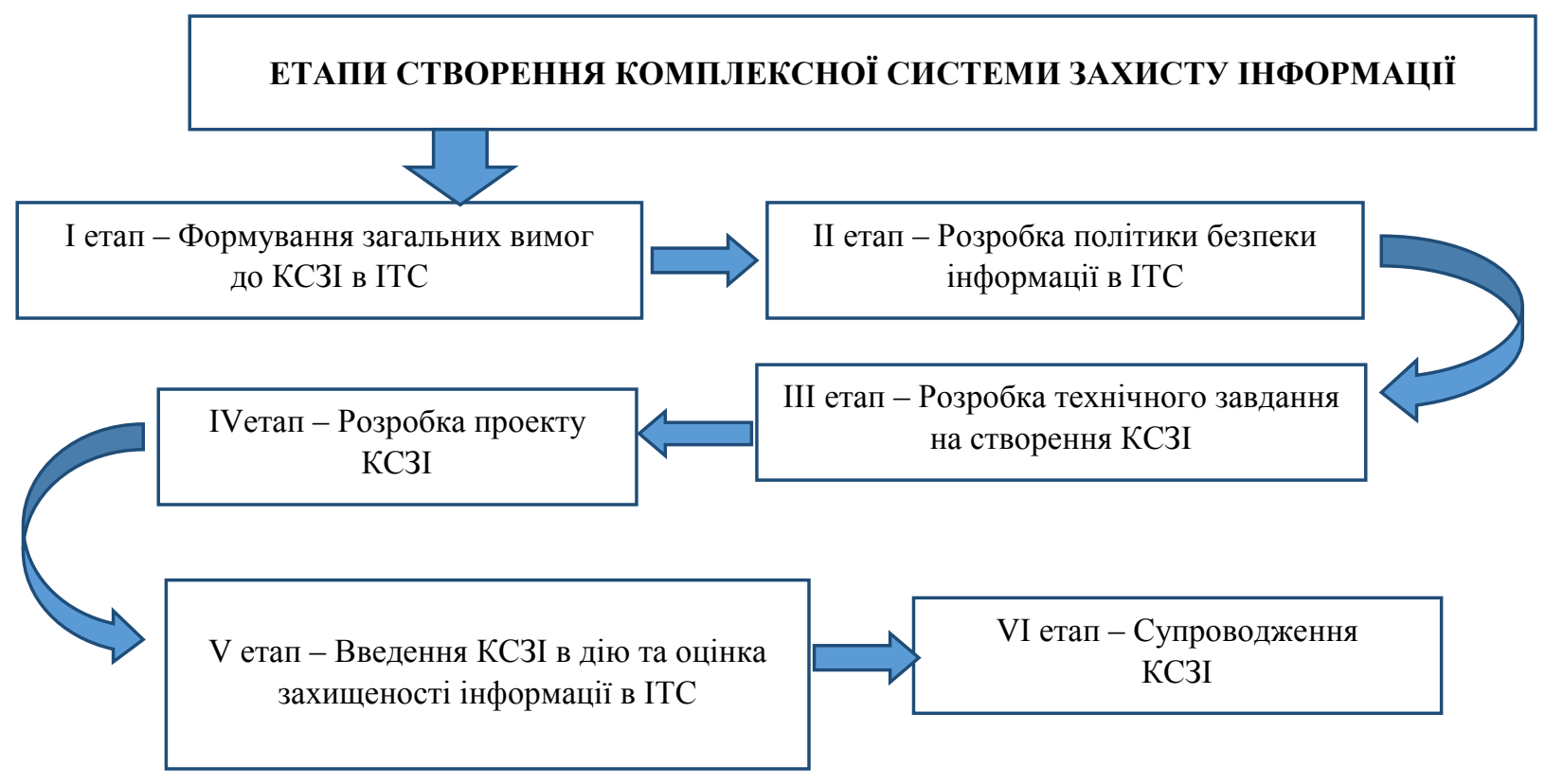

Рис.1. Етапи створення комплексної системи захисту інформації Джерело: розроблено автором [11].

Кожен день тисячі систем та мереж в усьому світі пропускають через себе терабайти даних. Інформація, що міститься в цих потоках, може містити відомості, розкриття яких може понести (і понесе) вагомі наслідки, такі як: економічні збитки для власників, політичні прецеденти, інформаційні та виробничі збитки тощо.

Сучасна практика 3 питань інформаційної та кібербезпеки розрізняє та виділяє декілька основних методів проведення атак на системи захисту інформації, серед яких вирізняються як суто технічні методи (апаратне та програмне забезпечення), так i методи, що пов'язані із використанням психологічних та соціологічних прийомів впливу на людей, маніпуляцією людським фактором. В ході виконання дослідження під час проведення симуляції дій порушника контуру захисту інформації, було використано декілька основних 3 існуючих методів, а також надано рекомендації щодо усунення виявлених вразливостей. А саме:

1. Методи соціальної інженерії, які орієнтовано на проведення первинної підготовки перед проведенням атаки на системи захисту інформації, збір відомостей щодо організаційної структури цільового установи через канали витоку інформації, що відносяться до каналів людського фактору із використанням методів психологічного та соціологічного тиску та маніпулювання. Серед них окремо слід виділити:

- моніторинг публічних даних цілі;

- вербування агента серед співробітників організації; 
- фішінг (також відомо як “атака на неуважного");

- фармінг.

Здебільшого, методи соціальної інженерії використовуються при первинній підготовці до проникнення до систем та мереж зберігання та обробки інформації. Протистояти таким методам технічними засобами майже неможливо таким чином, щоб не порушити умови, що необхідні користувачам системи та мережі для виконання робочих обов'язків. Однак, можливо значно зменшити рівень вірогідності реалізації загрози з боку методів соціальної інженерії, оперуючи адміністративними та організаційними методами захисту.

2. Методи програмної інженерії, що для свого задіяння вимагають присутності спеціалізованого програмного забезпечення і використовуються, здебільшого, для закріплення успіху первинної атаки через людські фактори та для основної маси операцій із нейтралізації систем захисту інформації, проникнення до систем та мереж обробки, передачі та зберігання інформації. Серед них найбільш часто використовуваними є:

- MITM (Man-In-The-Middle), також відомий як “Атака посередника;

- RAT (Remote-Access-Trojan;

- BFPE (Brute-Force-Password-Engaging;

- LBPE (Logic-Based-Password-Engaging);

- TCPR (TCPReset);

- RtLA (Return-to-libc-Attack, атака “повернення до бібліотеки");

- DoS (Denial-of-Service).

3. Методи апаратної інженерії, що для свого використання вимагають присутності спеціалізованого апаратного устаткування та програмного забезпечення. Використання даних методів зустрічається рідше, ніж чисто програмні методи, оскільки спеціалізоване устаткування може вимагати великої кількості фінансових вливань або офіційного оформлення ліцензії на використання деяких типів суто спеціалізованого устаткування на кшталт сканерів радіоефіру, радіостанцій, моніторів електромагнітних імпульсів, прослуховуючих пристроїв тощо. Серед таких методів окремо можливо виділити:

- скіммінг;

- сканування ефіру за різними стандартами.

Взагалі, виявлення, протистояння та попередження використання даних методів для проникнення до мережі установи знаходиться в зоні відповідальності служби інформаційної безпеки установи. Однак в сучасних умовах установи та державні установи все частіше звертаються до незалежних спеціалістів для проведення тестування на проникнення до мережі із імітацією дій реального порушника (так званий “пентест”), щоб отримати більш повну картину стану захищеності інформації.
Перед тим, як проводити вторгнення в систему, необхідно провести аналіз відомостей, що можуть бути отримані з відкритих джерел та шляхом соціальної інженерії, а також заздалегідь підготовити спеціалізовані апаратні ресурси та П3, що буде задовольняти деяким мінімальним вимогам та потребам та використання яких не буде порушувати умов ліцензування.

Проведення тестування на проникнення буде проводитися за допомогою наступного апаратного забезпечення:

- персональний портативний комп'ютер на базі х86-64-сумісної системи.

Характеристики пристрою:

- Intel Core i3-8130u quad-core 2.4Ghz CPU- 16

Gb DDR4-2400 RAM;

- NVIDIA GeForce MX-130 2Gb GDDR5 main

GPU- Intel UHD Graphics 620 secondary GPU;

$-120 \mathrm{~Gb}$ m.2 TLC SSD;

- 120 Gb SATA-III TLC SSD;

- 1Tb SATA-III-7200 HDD;

- Qualcomm Wireless Multiadapter;

- Смартфон на базі ARM-сумісної архітектури під управлінням OC Android;

- Смартфон на базі ARM-сумісної архітектури під управлінням OC KaliNethunter;

- Realtek WLAN USB controller - додатковий адаптер стандарту Wi-Fi, необхідний для можливості мати одночасно адаптери в режимі клієнту та в режимі монітору.

На сайті установи розташовано декілька фотографій $з$ публічних заходів, що дозволило відстежити деяких співробітників установи та встановити їх особи, використовуючи публічні сервіси пошуку по фотографії (такі як пошук Googleпо зображеннях), соціальні мережі та інші засоби соціальних досліджень.

Згідно з відкритими джерелами, а також орієнтуючись на основний профіль установи, можна зробити висновки про те, що на установі реалізовано багаторівневу модель доступу до службових даних, загальні принципи та параметри якої визначено та охарактеризовано в роботі [12], а саме:

- параметри важливості даних, що визначають: кількість користувачів, що можуть мати доступ до тих чи інших даних; статус та рівень доступу користувачів; типи задач, що розв'язуються на установі із використанням інформації із обмеженим доступом та інформації службового використання; час та кількість одночасних використань носіїв цієї інформації; початковий та кінцевий рівні конфіденційності та строки їх пониження тощо.

- Параметри рівня зв'язаності даних між собою, що визначають середовище інтерпретації, зберігання та обробки даних, умови доступу до одних даних без можливості порушення режиму доступу 
до інших та визначаються типом задач, що виконуються користувачем.

- Параметри часу існування та функціонування даних, що визначають стабільність даних у часі, їх динамічність та частоту використання даних.

Із отриманих з відкритих і обмежених джерел даних, можливо зробити висновки про те, що адміністративно система установи поділена на основні групи безпеки, для кожної з яких налаштовано свої правила та можливості. Орієнтуючись на стандартну схему будь-якої установи, дані про послуги із офіційного сайту установи, можливо розробити схему груп безпеки та приблизні обмеження та повноваження кожної групи.

Проведений аналіз відкритих даних дав можливість провести первинне вторгнення в систему шляхом фішингової розсилки для отримання даних для входу в систему. Для отримання даних авторизації та автентифікації в системі методами соціальної інженерії, створюється фіктивний обліковий запис на локальному сервері, що буде зовсім трохи відрізнятися від реальної адреси на корпоративному поштовому сервері (в даному випадку - не username@ted.ua, a username@teb.ua) та розсилається фіктивне повідомлення від, начебто, легітимного користувача.

Отримавши дані від одного з користувачів пер- шої лінії технічної підтримки, підключаємося до мережі установи у позаробочий час. Це нормальна практика, якщо співробітник технічної підтримки підключається віддалено до свого робочого місця, а отже підозрілої активності в мережі не буде видно.

Використовуючи спеціалізоване ПЗ, наприклад - Total Network Monitor, сформуємо для себе карту корпоративної мережі. На рис. 2. запропоновано узагальнену організаційну схему мережі установи, на основі якої буде проводитися планування методів та засобів проникнення до мережі установи.

Скомпрометований обліковий запис, згідно 3 нормами доступу для співробітників першої лінії технічної підтримки, що впроваджені на установі, має доступ до всіх робочих станцій. Для спрощення подальшого доступу до системи, запишемо собі ідентифікаційний номер засобів віддаленого доступу до робочої станції співробітника засобами TeamViewer. Даний засіб не контролюється системою облікових записів Active Directory, розгорнуту на установі. Окрім того, налаштуємо собі неконтрольований доступ, а також зробимо собі копію сертифікатів безпеки та сертифікатів віддаленого доступу для підключення до мережі установи за допомогою корпоративного VPN-сервісу без необхідності підключення до робочої станції.

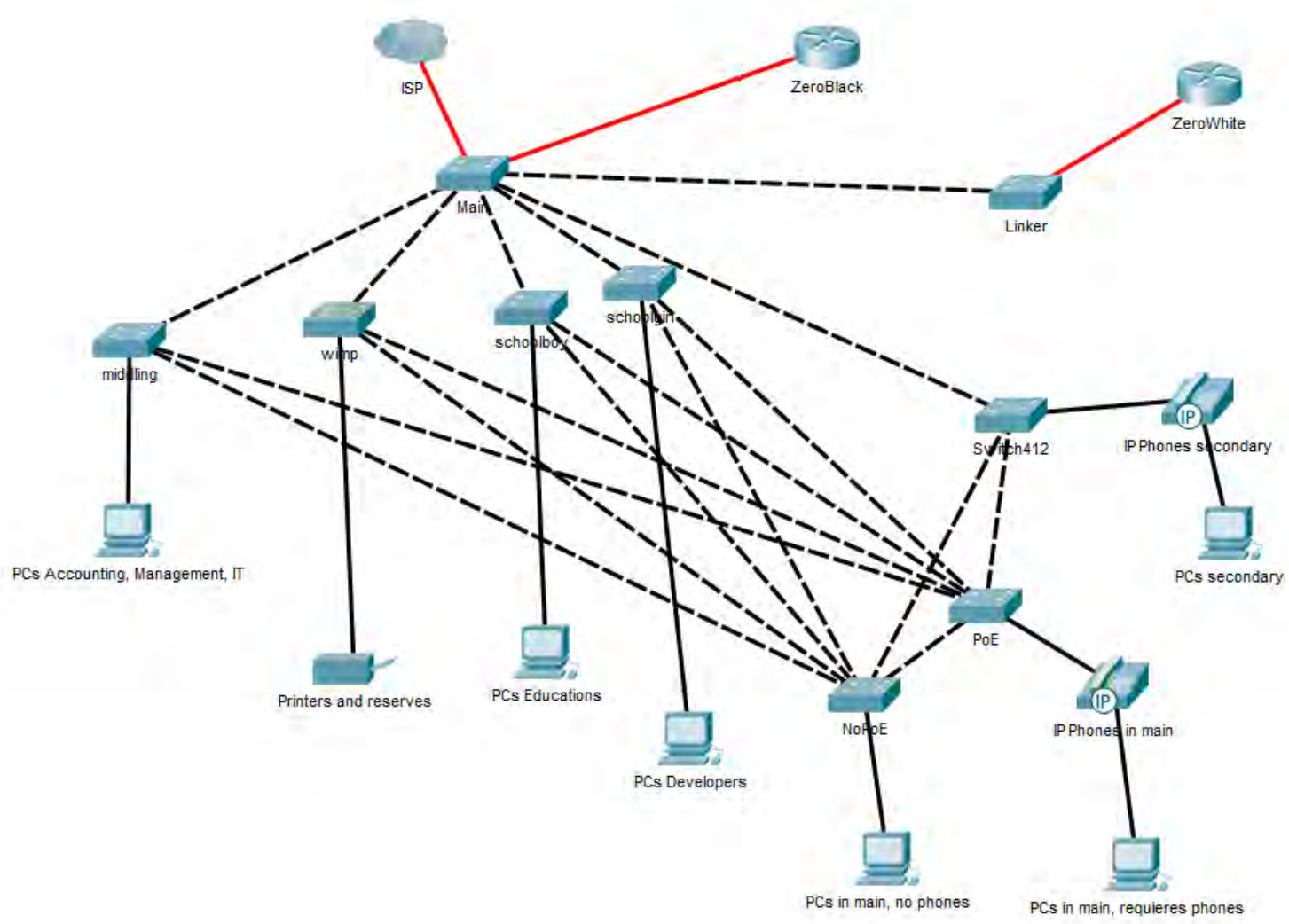

Рис. 2. Загальна структура комутації установи Джерело: розроблено автором. 
У наведеній вище схемі зображено загальну структуру комутації установи із умовними позначеннями комутаторів, маршрутизаторів та засобів клієнтського доступу до мережі (система телефонії та комп'ютерна мережа по відділам).

Між двома маршрутизаторами Zero Black та ZeroWhite налаштовано протокол VRRP (Virtual Router Redundancy Protocol), що дозволяє збільшити відмовостійкість мережі за рахунок об'єднання фізичних пристроїв в один віртуальний маршрутизатор, призначити їм загальну IP-адресу, яку будуть використовувати як шлюз за замовченням всі пристрої в мережі [13]. Мережа розподілена на VLAN, що дозволяє призначати та керувати політиками безпеки мережі для кожного окремого відділу.

Окрім цих віртуальних мереж, існують окремі підмережі для деяких відділів, віртуальні приватні мережі (VPN) для зв'язку із центрами обробки даних та систем деяких клієнтів, однак поточний рівень облікового запису має лише обмежений доступ до них. Також для співробітників із портативними ПК налагоджено доступ до корпоративної бездротової мережі, що інтегрована в загальну мережу офісу шляхом віртуальних локальних підключень. Дана бездротова мережа є прихованою для стандартних засобів підключення, підключення до неї для кожного корпоративного ПК виконується на етапі налаштування ОС та введення ПК в домен.

Отримана в ході первинної розвідки інформація надає можливість зробити висновки про рівень захищеності комп'ютерів користувачів та рівень соціальної відповідальності користувачів. Дані висновки дають представлення про те, що на установі використовується стандартна в більшості випадків політика безпеки паролів і відсутність жорсткого контролю за виконанням її вимог, що дозволяє припустити наявність слабких паролів в системі. Для спрощення підбору даних паролів, автором роботи використано генератор паролів в діапазоні від 8 до 10 символів із алфавітом, що складається з цифр, англійських букв малого та великого регістру, а також готові словники паролів, що розповсюджуються вільно на безкоштовній основі.

Отримавши базовий доступ до мережі, можливо проводити подальші дослідження систем захисту інформації, отримуючи глибокий контроль над корпоративною мережею. Для досягнення оптимального контролю над мережею, необхідним і достатнім результатом буде отримання доступу до ключової інформації установи та хоча б по одному співробітнику в кожній групі користувачів.

Отримання IP-адрес необхідно для використання деяких спеціалізованих програм, що не вміють автоматично перетворювати DNS-імена в адреси хостів, що мають бути атаковані. Дане перетворення виконується за допомогою демону "DIG" -
Domain Information Groper, що $\epsilon$ альтернативою nslookup в UNIX-подібних системах.

Подальшим етапом, після отримання інформації про IР-адреси, є отримання переліку відкритих портів на хостах для подальшого використання цих відомостей при застосуванні експлоїтів. Дана задача вирішується за допомогою П3 Nmap. Оскільки під час первинної розвідки об'єкт захисту ми отримали доступ до корпоративної VPN-мережі, а також отримали копії сертифікатів безпеки, то при підключенні до VPN під виглядом скомпрометованого облікового запису, ПЗ Nmap буде орієнтуватися саме на дане підключення. Після введення необхідних параметрів, отримуємо за деякий час інформацію про відкриті порти на необхідних комп'ютерах.

Отримана інформація про порти в купі із IPадресами надає можливість використання експлоїтів для неконтрольованого НСД до персональних комп'ютерів користувачів із інтерфейсом командного рядка. Використовуючи даний доступ, можливо завантажити шкідливе ПЗ або отримати з віддалених комп'ютерів будь-які файли або запитати будьяку необхідну інформацію по скомпрометованій робочій станції.

Використання методів соціальної інженерії не завжди є практичним та можливим методом проникнення, оскільки при розкритті фейкового листування можливе стрімке підвищення рівня захищеності та прийняття мір протидії проникненню, серед яких:

- позапланові зміни паролів користувачів;

- обмеження підключень до VPN-сервісу;

- періодичне сканування комп'ютерів в мережі;

- тимчасове блокування зовнішніх підключень;

- блокування підключення для IPабо МАCадреси;

- обмеження прав доступу скомпрометованого облікового запису;

- передача листом завідомо неправдивих відомостей;

- трасування зовнішніх підключень та виявлення положення комп'ютера, з якого відбувається підозріле підключення;

Зважаючи на вищеозначені фактори, розумним кроком буде розробка альтернативних методів підключення до мережі. Одним 3 таких методів може стати перехоплення та дешифрування інформації 3 підключення до бездротового елемента інформаційно-комунікаційної мережі установи - корпоративної та гостьової мереж стандарту Wi-Fi. Перевагою даного методу є відсутність необхідності безпосередньо контактувати із представниками та співробітниками установи. Найбільш вагомим недоліком даного методу можливо вважати необхідність особистої чи агентської присутності на об'єкті дослідження або безпосередньо поруч із ним (в радіусі дії бездрото- 
вих точок доступу), а також відносно велику кількість часу (від декількох годин до декількох діб), що необхідно для відновлення паролю. На представленому в роботі об'єкті є можливість непомітної особистої присутності.

Для проникнення до бездротової мережі було використано методи LBPE, MITMта TCPR, що включені до комплекту Aircrack-ng. За допомогою програмного забезпечення Responder було виявлено, що в мережі існує тестовий обліковий запис із простим паролем, що можливо підібрати методом повного перебору за декілька хвилин. Згідно до отриманих відомостей, даний запис використовується на установі при віддаленому підключенні до тестового середовища. Використовуючи даний обліковий запис, можливо провести таке саме вторгнення, як і описано раніше, а також додатково отримати доступ до гостьової підмережі, що дасть можливість отримати контроль ще й над клієнтами організації.

Доступність ресурсів є важливим аспектом нормального функціонування інформаційнокомунікаційних мереж. Проведення стрес-тестів може дати важливу інформацію відносно проблем, пов'язаних із апаратними та програмними ресурсами серверного та клієнтського обладнання, зокрема: достатність потужності серверів; повнота та коректність їх налаштування; рівень максимальної завантаженості ресурсів; час, що необхідний для повної відмови ресурсів при максимальному завантаженні; час, що необхідний для повного відновлення функціоналу ресурсів; оперативність систем моніторингу завантаженості серверів та систем попередження загрозам.

Оскільки для об'єкта, що підлягає захисту, доступність ресурсів є критичною, проводимо стрестест. Використовуючи інформацію про доменні сервіси (а саме - доменні імена, адреси серверів та види сервісів, що функціонують на кожному сервері та рівень їх зв'язаності між собою), а також спеціалізоване ПЗ, що дозволяє проводити симуляції атак на відмову ресурсів (т.з. Denial-of-Service або DoS) та проводити заміри продуктивності функціонування ресурсів, проводимо стрес-тестування наступними методами:

- Slowloris - атака шляхом постійного ТСРтаймера, що займає собою майже весь пул підключень шляхом неповноти даних в запиті;

- Apache Range Header- атака шляхом впливу на заголовки пакетів, що викликає велике завантаження центрального процесора та оперативної пам'яті;

- Slow Read - атака шляхом маніпуляції швидкістю обробки пакета сервером та швидкістю прийняття відповіді клієнтом, що викликає велике навантаження на мережу;
- Ping Flood - найпростіша атака, суть якої полягає в забиванні мережевого каналу серверу великою кількістю ехо-пакетів. Даний тип атак зазвичай хибно вважається єдиним методом DoS-атак;

- ICMP Smurf - одна 3 найважчих для системи атак, суть якої полягає у відправленні в мережу жертви великої кількості підроблених ICMP-пакетів, в яких адресою відправника буде зазначено комп’ютер цілі. Таким чином - чим в більшій мережі знаходиться ціль, тим із більшою вірогідністю атака буде виконана успішно;

- атака другого роду - достатньо груба і примітивна атака, суть якої в навмисному викликанні на себе реакції систем захисту інформації таким чином, щоб заблокувати одночасно і ресурс, який дана система захищає;

Виходячи $з$ даних, що було отримано під час виконання тестування на проникнення до інформаційно-комунікаційної мережі установи, можемо сформувати певні результати щодо стану захищеності інформації в корпоративній мережі установи та рекомендації щодо вдосконалення систем захисту інформаційно-комунікаційної мережі установи від НСД.

В ході проведення тестування на проникнення було виявлено некритичні вразливості систем інформаційної безпеки установи, більша частина яких базується на недосконалості ПЗ, що використовуються в інформаційних системах установи і може бути виправлена. Для цього необхідно:

- своєчасне встановлення оновлень запропонованих в центрі оновлень Microsoft, а також оновлених компонентів в дистрибутивах Linux;

- своєчасне оновлення несистемного програмного забезпечення;

- відмова від використання великої кількості програмного забезпечення, що дозволяє встановлювати неконтрольоване віддалене підключення або суворий контроль над трафіком, що генерується даним програмним забезпеченням;

- обмеження на підключення до VPN-cервісу комп'ютерів, що не введено в домен, ведення логів підключення та відстеження МАC та IP-адрес абонентів, що підключаються до мережі;

- перепланування карти розташування точок бездротової мережі для обмеження зони покриття Wi-Fiв межах офісного приміщення;

- сегментація мережі на більш дрібні віртуальні підмережі для забезпечення зменшення витрат часу на відновлення функціоналу після атак на доступність ресурсів;

- проведення профілактичних та навчальних бесід зі співробітниками щодо забезпечення інформаційної безпеки, дотримання ними норм листування, політики конфіденційності установи, стандартів на паролі, тощо; 
- проведення періодичних навчань та симуляцій ситуацій проникнення до інформаційнокомунікаційної мережі;

- введення обов'язкового контролю складів паролів на відповідність сучасним вимогам;

- введення заборони на стандартні паролі, що включені в перелік небезпечних паролів;

- введення дисциплінарних покарань за порушення норм інформаційної безпеки;

- введення антивірусного ПЗ на персональних комп'ютерах користувачів (наразі використовується Windows Defender на робочих станціях, що не задовольняє потреб користувачів в інформаційній безпеці);

- розмежування доступу до папок на загальному файлосховищі, періодичні перевірки документів, що відправляються в загальне файлосховище на присутність інформації, що має бути обмежена в доступі;

- введення обмежень та фільтрація інформації (в тому числі - фотографій та відеозаписів), що відправляється на веб-сторінку та групи установи в соціальних мережах.

\section{Висновки}

Таким чином, в процесі проведеного дослідження було з'ясовано роль процесу захисту інформації в інформаційно-комунікаційних системах та мережах, визначено порядок формування систем захисту інформації, їх використання, стандарти, що стосуються захисту інформації, класифіковано методи захисту. Проведені первинна розвідка та тестування на проникнення методами програмної інженерії дозволили виявити вразливості досліджуваної установи. Повний перелік вразливостей системи було передано керівництву разом із переліком розроблених рекомендацій щодо усунення недоліків системи та подальшого розвитку засобів захисту інформації в ІКСМ установи. Проведене дослідження дало змогу підвищити рівень захисту ІКСМ досліджуваної установи від несанкціонованого доступу (за попередніми розрахунками - більше ніж на 35\%) за рахунок чого значно знизився ризик реалізації загрози вторгнення.

\section{Список літератури}

1. Шорохова Г.М. Проблема вдосконалення інформаційного забезпечення діяльності правоохоронних органів України [Електронний ресурс] / Г.М. Шорохова. - Режим доступу: http://univd.edu.ua/science-issue/issue/343.

2. Закон України “Про захист інформації в інформаційно-телекомунікаційних системах № 26 від 2005 р.” [Електронний ресурс]. - Режим доступу: https://zakon.rada.gov.ua/laws/show/2594-15.

3. Тарнавський Ю.А. Технології захисту інформації [Електронний ресурс] / Ю.А. Тарнавський. - К.: КПІ ім. I. Сікорського, 2018. - 162 с. - Режим доступу: https://ela.kpi.ua/bitstream/123456789/23896/1/TZI_book.pdf.

4. Маслянко П.П. Концепція інформатизації корпоративних структур / П.П. Маслянко // Наукові вісті національного технічного університету України “Київського політехнічного інстиуту”. - 2003. - № 3. - С. 510-525.

5. Іванова О.М. Характеристика та класифікація інформаційних потоків установ [Електронний ресурс] / О.М. Іванова // Інвестиції: практика та досвід. - 2016. - № 13. - С. 18-22. - Режим доступу: http://www.investplan.com.ua/pdf/13_2016/5.pdf.

6. Конституція України “Відомості Верховної Ради України № 30 від 1996 р.” [Електронний ресурс]. - Режим доступу: https://zakon.rada.gov.ua/go/254\%D0\%BA/96-\%D0\%B2\%D1\%80.

7. Указ президента України "Про Доктрину інформаційної безпеки України рішенням Ради національної безпеки i оборони України від 29.12.2016 р.” [Електронний ресурс]. - Режим доступу: https://zakon.rada.gov.ua/laws/show/47/2017\#n12.

8. Постанова КМУ "Про затвердження Концепції технічного захисту інформації в Україні № 1126 від 08.10.1997 p.” [Електронний ресурс]. - Режим доступу: https://zakon.rada.gov.ua/laws/show/1126-97-\%D0\%BF.

9. Закон України “Про інформацію № 48 від 1992 р.” [Електронний ресурс]. - Режим доступу: https://zakon.rada.gov.ua/laws/show/2657-12.

10. Нашинець-Наумова А.Ю. Організація системи захисту інформації суб'єктів господарювання [Електронний ресурс] / А.Ю. Нашинець-Наумова // Підприємництво, господарство і право. - 2016. - № 2. - С. 110-116. - Режим доступу: http://pgp-journal.kiev.ua/archive/2016/02/23.pdf.

11. Нормативні документи 3 питань захисту інформації ТЗІ 3.7-003-05 Порядок проведення робіт із створення комплексної системи захисту інформації в інформаційно-телекомунікаційній системі [Електронний ресурс]. - Режим доступу: http://surl.li/gnbi.

12. Суліма О.А. Методи організації захисту доступу до інформаційних систем на основі використання багаторівневих моделей: автореф. дис. ... канд. техн. наук: 05.13.21 [Електронний ресурс] / Суліма Олександр Андрійович. - К., 2017. - 23 с. - Режим доступу: http://er.nau.edu.ua/handle/NAU/30881.

13. Стандарт RFC 5798. IETF [Електронний ресурс]. - Режим доступу: https://tools.ietf.org/html/rfc5798. 
Information about the author:

Храпкін Олександр Максимович

магістр

Державного університету інфраструктури та технологій, Київ, Україна

https://orcid.org/0000-0002-2281-9581

\section{Oleksandr Khrapkin}

Master Student

of State University Infrastructure and Technology,

Kyiv, Ukraine

https://orcid.org/0000-0002-2281-9581

\title{
ЗАЩИТА ИНФОРМАЦИОННО-КОММУНИКАЦИОННОЙ СЕТИ УЧРЕЖДЕНИЯ ОТ НЕСАНКЦИОНИРОВАННОГО ДОСТУПА
}

\author{
А.М. Храпкин
}

В статье освещчен вопрос возможности проникновения в информационно-коммуникационную сеть учреждения, проанализированы и симулированы действия реального нарушителя контуров защиты информации на примере реальной информационной инфраструктуры, приведен общий порядок оценки и обеспечения совериенствования систем заичиты информации путем проведения тестирования на проникновение. Предложенные методы проведения тестирования на проникновение могут использоваться при разработке и тестировании новых систем зашиты информации, а также оценки эффективности и совершенствования уже существуюших систем. Результаты могут быть использованы в сфере защиты информации, в том числе в современных информационно-коммуникационных системах и сетях для оченки и повышения эффективности применения комплексных систем и отдельных средств защиты информации в современных ИКС.

Ключевые слова: защчита информачии, несанкционированный доступ, тестирование на проникновение, оценка эффективности защиты, сочиальная инженерия, программная инженерия, практическая защита информации.

\section{PROTECTION OF THE COMPANY'S INFORMATION AND COMMUNICATION NETWORK FROM UNAUTHORIZED ACCESS}

O. Khrapkin

The article considers the possibility of penetration into the information and communication network of the enterprise, analyzes and simulates the actions of a real violator of information protection contours and profiles on the example of real information infrastructure. This actions included such technics like public data analyzing, phishing attacks, data mining, network monitoring, man-in-the-middle attack, password engaging using brute-force and logic-force combinations, rainbow-tables attacks, backdoor injections, network monitoring etc. That research provides a general, typical procedure for assessing and improving information protection systems by penetration testing and security systems analysis by Gray Box technic. This technic means, that penetration tester knows general information about infrastructure and network working principal plan, schemas, datagrams, other information that could be marked as public information or as non-restricted information and usually has an access to the technical information and documentation archives. The proposed methods of social engineering, vulnerabilities exploitation and software engineering in penetration testing procedure can be use in the development and testing of new information security systems, intrusion detection systems, and intrusion protection systems as well as evaluating the effectiveness and improvement of existing protection systems, security and general software, cloud platforms, enterprise networks and computing systems. The results of this research can be use in the field of information and cyber security, in particular in modern information and communication systems and networks to assess and improve the effectiveness of integrated systems and individual means of information protection in modern Information and Communication Systems and Networks.

Keywords: information protection, unauthorized access, penetration testing, evaluation of protection effectiveness, social engineering, software engineering, practical information protection. 